\title{
Patient Information System and Doctor Competence in Increasing Satisfaction and Loyalty to Primary Level Health Service
}

\author{
Nur Choirul Afif*, Lusi Suwandari* \\ * Correspondence Author: lusi.suwandari@unsoed.ac.id \\ * Jenderal Soedirman University, Purwokerto, Banyumas City, Central Java, Indonesia
}

\section{N D E X I N G}

Keywords:

SIM;

Doctor Competence;

Patient Satisfaction;

Loyalty;

\section{Kata Kunci:}

SIM;

Kompetensi Dokter:

Kepuasan;

Loyalitas;

\begin{abstract}
A B S T R AC T
The establishment of Puskesmas (Community Health Centers) aims to make it possible for communities to get quality services that are affordable for all levels of society. The things that are necessary to be improved in the services of Puskesmas are the quality and access. This study aimed at predicting the factors influencing satisfaction and loyalty of BPJS patients of the primary level health facility. This research was an explanatory study aiming at determining whether there is an influence of management information system and doctor competence on patient satisfaction and patient loyalty. The results showed that the management information system (SIM) of the patients had a positive and significant influence on the BPJS patients' satisfaction; doctor competence had a positive and significant influence on the BPJS patients' satisfaction; the management information system (SIM) of the patients had a positive and significant influence on BPJS patients' loyalty to the primary level health facility in Banjarnegara; doctor competence had a positive and significant influence on the BPJS patients' loyalty, and patient satisfaction had a positive and significant effect on the BPJS patients' loyalty to the primary level health facility in Banjarnegara.
\end{abstract}

Article history: Received 2019-Feb-15; Revised 2019-Mar-02; Accepted 2019-Apr-25

\section{INTRODUCTION}

Community Health Centers are established in order that communities can get quality services that are affordable for all levels of society. The things that need to be improved regarding Puskesmas are the access and quality of the services. In terms of the access, it is necessary that Puskesmas provide convenience and offer affordable costs to all levels of society, including to those who are less fortunate. As for the service quality, it is indicated by the medical services that are fast, easy, and good in quality. Many things should be addressed to enhance health services of Puskesmas. However, the first thing that is considered important and urgent in order to improve the services to the communities is an improvement in the management information system (Sistem Informasi Manajemen) about the patients.

Management Information System (SIM) is a collection of subsystems or components that are interconnected and work together to help managers in organizational decision making. ${ }^{-1}$ An integrated management information system can help doctors diagnose their patients' diseases. Management Information System concerning a patient provides information on the types of diseases suffered by him, so that it can be anticipated the types of drugs, medical equipment, and specialists that need to be provided by the primary level health facility, Puskesmas. In this case, doctors are human resources who deal directly with patients, the customers. Thus, a doctor should be able to act as a marketer, who 
strives to analyze the needs of their customers, the patients. If the doctor can serve the patients well and meet their expectations, the patients will be satisfied with the doctor's services.

The paradigm of business organizations has been shifting from production concept, product concept, to marketing concept. In the era of production concept, it was the consumers who need the companies, so that the companies undertook mechanization to produce as many units as possible. The current development has arrived at the era of marketing concept, where business organizations need to emphasize analysis of consumers' needs, desires and expectations about products. ${ }^{-}$

One of the problems faced by Puskesmas is that the information system about the patients is still manual, so that it is difficult for officers to get accurate medical records. This resulted in some cases where one patient had more than one medical record; there was even a patient who reported that they had had 4 (four) medical records. These cases made it difficult for doctors to diagnose patients' diseases due to not getting accurate information. The above conditions made patients not get the expected quality of medical services.

\section{LITERATURE REVIEW}

\section{Loyalty}

Customer loyalty in a long run is always a goal in strategic market planning. ${ }^{2}$ In addition, it is also used as a basis for development of sustainable competitive advantage, an excellence that can be achieved through marketing efforts..$^{-}$Loyalty is a measure in determining marketing performance. It is marketers' task to obtain, maintain, and increase the number of customers. Customer loyalty is identified as a key factor in service businesses because it is a strong and positive relationship between customers and service providers. ${ }^{4}$ There are eight indicators to measure service loyalty based on behavioral, attitudinal, and cognitive loyalty, i.e. repetitive buying behavior, wordof-mouth recommendations, continuous purchase intention, price tolerance, repeat purchase intention, preference, choice reduction behavior, and first-in-mind indicator. ${ }^{-5}$ The loyalty measurement in this study used the model of Johny and Esther as it was considered capable of reflecting behavioral, attitudinal, and cognitive loyalty simultaneously..$^{-}$

\section{Patient Satisfaction}

Patient satisfaction is the most important factor in determining marketing performance of health services. ${ }^{17}$ In this case, the organizations must try to convey values more than what customers expect. If doctors are unable to provide values as expected by patients, the patients, as the customers, will be disappointed.

Customer satisfaction is defined as a person's feeling regarding either pleasing or disappointing conditions of the performance of a product and/or a service in relation to the expectation about the product and/or the service..$^{-}$Customer satisfaction can only occur when a service company is able to anticipate what consumers want from their products or services. ${ }^{-}$

Customer satisfaction can provide a good basis for repurchase, customer loyalty creation, and stimulating word-of-mouth recommendations, which are profitable for the company.11 Consumers who are satisfied will reorder the same services, whereas those who aren't may tell others about the bad experience. ${ }^{13}$

Customer satisfaction results in profits for the company. -6 Generally, high customer satisfaction will mark consumer loyalty increase. The increased customer loyalty means that customers will have a good perception of the company, and make another purchase in the future. Many studies have found that customer satisfaction plays a mediating role in the relationship between service quality and customer loyalty. ${ }^{7,4}$

Information system, in this case, is a form of intangible services for patients that can trigger customer loyalty. ${ }^{19}$ Higher satisfaction leads customer loyalty, which means that there will be an intention to make another purchase of the product or service..$^{-}$From the above description a hypothesis can be made:

H1. There is a positive influence of satisfaction on patient loyalty

\section{Management Information System}

Any organization would need to have a system to understand desires and expectations of consumers about products. Thus, it is needed an information system that can fulfill those desires and expectations. A system is a collection of subsystems or components that are interconnected and work together to achieve the management goal, namely decision making. ${ }^{1}$ Thus, management information system (SIM) about a patient means a collection of subsystems or components that are interconnected and work together to achieve the goal, i.e., collecting information about the patient.

The use of information technology is to produce companies that are competent, trustworthy, and integrated with customers for customers' behalf, so that all processes 
and interactions with customers can help maintain and improve profitable relationships. ${ }^{-}$Marketers of public organizations need to design electronic Customer Relationship Management (e-CRM) with the method of dynamic framework to be used as the information technology that is oriented to customer satisfaction. Customer satisfaction is expected to provide long-term benefits for the public organizations, which, in the end, can provide long-term benefits for the patients as well. ${ }^{19}$ The eCRM system integrates sales, marketing, and customer service units in the form of two-way communication, i.e., to and from patients, concerning what patients need, and can increase customer satisfaction with such public organizations like community health centers and hospitals.

The system allows patients who have long used hospital services to provide information or data regarding their needs to keep and maintain a good relationship between them and the hospitals by providing useful services and supporting applications. By processing the information, it will be obtained the data of patients' behavior, who show more tendency of willingness to be cared for and served well and to get good responsiveness from the hospitals, as the service providers, to them, and usually the tendency will make them not regard the amount of money they should spend. The condition where patients tend not to see the amount of prices issued can be one indicator that they have had loyalty to the hospital. From the description above it can be made hypotheses as follows: $\mathrm{H} 2$ : There is a positive influence of management information system on patient satisfaction

H3: There is an influence of management information system on patient loyalty

\section{Doctor Competence}

Competence is a condition where a person can do something better and faster, and with high motivation to do a job. Thus, doctor competence is defined as the ability of doctors to diagnose patients' diseases and treat them effectively and efficiently. According to the Indonesian Medical Council in 2015, doctor competence standards for the implementation of medical professional education are the minimum criteria that must be achieved by every graduate of medical education institutions in Indonesia, so that they can provide services to the community with standardized quality. This competency standard includes domains, core competencies, supporting competencies, and basic capabilities.

Indonesian Doctor Competency Standards (SKDI) year 2015 is a minimum standard of competence of a medical graduate as a provision of knowledge and skills to become a doctor..$^{10}$ In SKDI, there is a division of the capability level that must be achieved.

1. A doctor is only asked to be able to recognize and explain clinical description of disease, and find out the most appropriate way to get more information about the disease, then determine the most appropriate references for the patients.

2. A doctor is only asked to be able to make a clinical diagnosis of the diseases and determine the most appropriate references for the further treatment.

3. A doctor must be able to make a clinical diagnosis and provide preliminary therapy both in nonemergency and emergency situations.

4. A doctor must be able to make a clinical diagnosis and manage the disease independently and thoroughly at the end of the education period..$^{10}$

Based on Law of Republic of Indonesia No. 36 of 2009 article 1 paragraph 11, the meaning of health attempts and services is every activity and / or a series of activities carried out in an integrated and sustainable manner to maintain and improve health status, treat diseases, and do health recovery by the government and / or the community. $\frac{16}{}$

Service quality that is expected by patients includes fast service, good attitudes and behavior of employees (including doctors and other employees), and clarity of information provided. ${ }^{11}$

Healthcare with patient satisfaction can become an activity perceived in a relationship between a health service provider and the patients, where the health service provider can meet expectations, desires, and needs to provide satisfaction to the patients, which is meant by a doctorpatient relationship.

To produce service quality that is in accordance with patients' expectations, there should be competencies of the human resources, especially the doctors, who are directly related to the treatment process. Doctors' competence in serving patients is not only about their expertise and knowledge, but also about their emotional condition, communication and attitude to the patients. The competence of doctors and nurses can lead to higher patient satisfaction since it can make the recovery of patients faster. Praises and higher rewards or compensations can be obtained both from the patients and the managements.

Today, patient satisfaction (PS) index are an important indicator of the efficacy, quality, and feasibility of healthcare services. In the 2014 research of Boquiren et al., it is stated the relationship between doctors and patients as 
a personal quality of health clinics, where the doctor's interpersonal characteristics and skills, expertise and professional leadership frequently compose most PS measures. .14 Particularly, a doctor's perceived technical skill and humaneness become the information for a patient's consideration about the healthcare services.

Competence is a motivating factor that can make

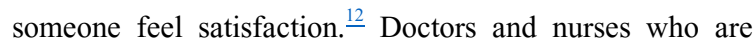
satisfied with their work because they have been able to help patients will make patients feel well, and will get the patients' positive response, i.e., that patients will be loyal to the hospital. From the above description, some hypotheses can be made:

H4: There is an influence of doctor competence on patient satisfaction

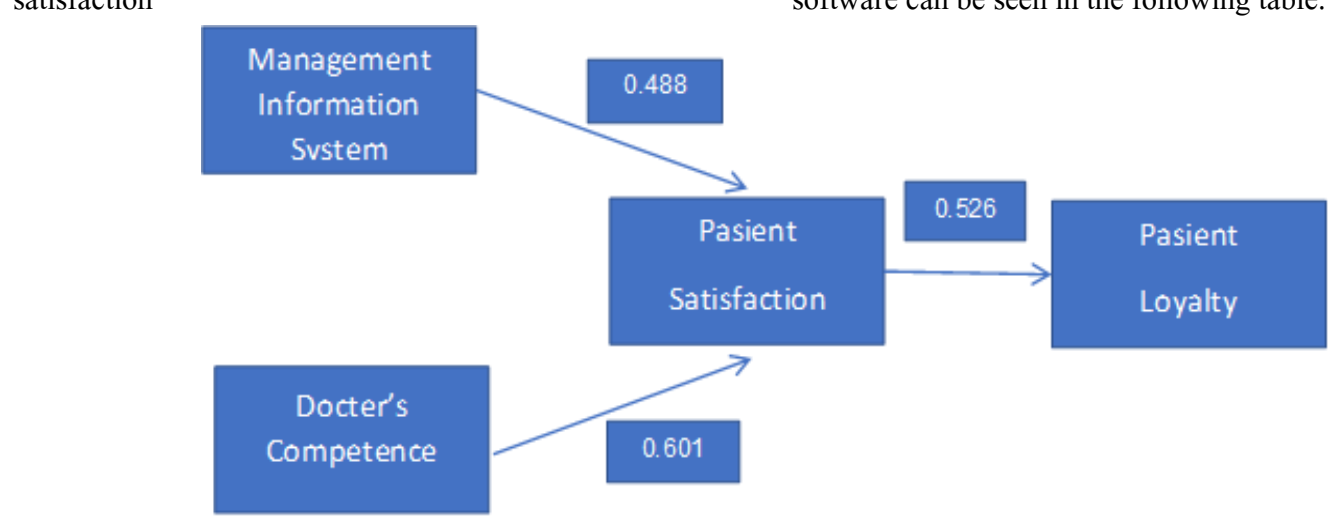

Figure .1 Path analysis model
H5: There is an influence of doctor competence on patient loyalty

\section{RESEARCH METHOD}

This was an explanatory research aiming to find out the relationship between one variable and other variables. The model testing used path analysis. The units of analysis in this study were 100 BPJS patients at the primary level health facility in Banjarnegara Regency, Central Java Province, as the respondents. The analysis design in the study was path analysis.

\section{RESULT AND DISCUSSION}

The results of statistical calculations using SPSS software can be seen in the following table.

The structure equation:

$\mathbf{X}=\mathbf{P} \mathbf{X}_{3} \mathbf{X}_{1}+\mathbf{b}_{2} \mathbf{X}_{2}+\mathbf{P X} \mathbf{X}_{2} \mathbf{X}_{2}+\mathbf{e}$

In the Model Summary Output, it is shown that R2 $=0.277$. It means that the contribution of management information system and doctor's competence is $27,7 \%$, while the remains are affected by other variables. The value of e 1 by the residue coefficient is $1-0.277=0.723$.

Table .1 Coefficient Line of the Effect of the Variables of SIM and Doctor Competence on Patient Satisfaction and Patient Loyalty

\begin{tabular}{lcc}
\hline & \multicolumn{1}{c}{ Non-Direct Influence } & Direct Influence \\
\hline Management Information System & $\rho_{z y x 1}=(0.488+0.526)=1.014$ & $\rho_{z x 1}=0.599$ \\
Doctor Competence & $\rho_{z y x 2}=(0.601+0.526)=1.127$ & $\rho_{z x 2}=0.520$ \\
Patient Satisfaction & & $\rho_{z y}=0.526$
\end{tabular}

Source: Processed by the researchers, 2018.

According to the explanation above, indirectly the doctor competence variable, which is 1.127 , has a greater coefficient than the management information system variable, which is 1.014 , while directly the management information system variable, which is 0.599 , has greater path coefficient compared to the doctor competency variable, which is 0.520 . This shows that the variables of management information system and doctor competence 
are very decisive (have a greater influence) on patient loyalty performance.

H1: The statistical test results showed that the direct effect of $\mathrm{Y}$ on $\mathrm{Z}$ was 0.526 percent with the $\mathrm{t}$-count value of 6.126 and the p-value of 0.000 . Thus, $\mathrm{H}_{0}$ was rejected and $\mathrm{Ha}$ was accepted, meaning that the patients' satisfaction had a positive effect on the patients' loyalty. It can be seen in the indicator having a loading factor above 0.7 according to the rule of thumb, where the indicator used in measuring customer satisfaction reflected patient satisfaction variable, and influenced patient loyalty.

H2: The hypothesis proposed was that the patient management information system (X1) has a positive effect on the patients' satisfaction (Y). The statistical test results showed that the direct effect of $\mathrm{X} 1$ on $\mathrm{Y}$ was 0.273 percent with the t-count value of 3.614 and the p-value of 0.002 . Thus, $\mathrm{H}_{0}$ was rejected and $\mathrm{Ha}$ was accepted, meaning that the patient management information system had a positive effect on the customers' satisfaction. This result supported Yunitarini's research that the use of information technology produces companies that are competent, trusted, and integrated with the customers. Information technology also supports all processes and interactions with customers, helping to increase profitable relationships. ${ }^{-}$

Management information systems can help patients know treatment fees, medical records, doctors' schedules, as well as number of queues and complaints. Each patient is identified according to the order or number of their respective applicable patient medical records to distinguish one patient from the others. This is evident in the loading factor value above 0.7 .

H3: The statistical test results showed that the direct effect of $\mathrm{X} 1$ on $\mathrm{Z}$ was 0.458 percent with the t-count value of 5.377 and the p-value of 0.000 . Thus, $\mathrm{H}_{0}$ was rejected and Ha was accepted, meaning that the patient management information system had a positive effect on the patients' loyalty. The skills of the medical personnel, the responsiveness of the health workers in meeting the patients' needs, as well as the factors of empathy, respect, and hospitality in serving patients could affect the quality of health services. The services from Puskesmas officers were supported by an information system that integrates the data of patients, as well as their medical records and drug use. In addition, the officers' friendliness, comfort, the patients' satisfaction with the drug use, and the doctors' competence triggered the patients' satisfaction with Puskesmas, which influenced the patients' loyalty. The loading factor value for all indicators of the variables of information system and satisfaction was above 0.6 .
H4: Based on the test results, the probability of tstatistics was smaller than the value of $\alpha(0.000<0.05)$, so that the decision to reject $\mathrm{H}_{0}$ was determined. Thus, the doctors' competence had a significant effect on the patients' satisfaction, which means that any changes in the doctor competence value would have a major impact on the patients' satisfaction. The doctor competence indicators, including the handling of disease and the use of sophisticated equipment, had the value of 0.7 .

H5: Based on the test results, the probability of $\mathrm{t}$ statistics was smaller than the value of $\alpha(0.000<0.05)$ so that the decision to reject $\mathrm{H}_{0}$ was determined. Thus, the doctors' competence had a significant effect on the patients' loyalty, which means that any changes in the doctor competence value would have a major impact on the patients' loyalty. The doctor competence indicators, a good attitude in treating patients and being able to overcome the problems of patients, had the loading factor of 0.5 , but still supported the high coefficient value of doctor competence towards loyalty.

\section{CONCLUSION}

Based on the research results and discussions described in the previous section, it can be concluded that management information system, doctor competence, and patient satisfaction have a relationship with patient loyalty. It needs to be explored further regarding the management information system dimension needed to achieve patient satisfaction. The accuracy in building the management information system dimension and indicators can build a value proposition for patients.

\section{REFERENCE}

1. Susanto, Azhar. (2009). Sistem Informasi Manajemen. Jakarta: Penerbit Lingga Jaya.

2. Kotler, Philip dan Kevin L. Keller.2012. Marketing Management (14th Edition). New Jarsey: Pearson Education, Inc.

3. Dominici, G., \& Guzzo, R. (2010), "Customer Satisfaction in the Hotel Industry: A Case Study from Sicily”. International Journal of Marketing Studies, 2(2), pp. 3-12.

4. Chodzaza, E. G. \& Gombachika, S. H. H. (2013), "Service Quality, Customer Satisfaction and Loyalty among Industrial Customers of a Public Electricity Utility in Malawi". International Journal of Energy Sector Management, Vol. 7 No. 2, pp. 269-282.

5. Johnny, Lu Ting Pong and Esther Tang Pui Yee. 2001. An Integrated Model of Service Loyalty. 
Academy of Business \& Administrative Sciences, International Conferences, Brussels, Belgium

6. Bennett, Rebekah and Bove, Liliana. (2002). "Identifying the key issues for measuring loyalty". Australasian Journal of Market Research, 9(2). pp. 27-44.

7. Namukasa, J. (2013). "The influence of airline service quality on passenger satisfaction and loyalty: The case of Uganda airline industry". The TQM Journal, Vol. 25 No. 5, pp. 520-532.

8. Abdullah, A.M.A, \& Kassim, N.M. (2009), "Measuring perceived service quality in Qatari Islamic banks". Journal International Business and Entrepreneurship Development, 4(1/2), 90-106.

9. Yunitarini, PB Santoso and H. Nurwasito. (2012). "Implementation of Electronic Software Customer Relationship Management (E-CRM) with the Framework of Dynamic Method CRM" Journal of EECCIS, vol. 6, pp. 83-90.

10. Konsil Kedokteran Indonesia. (2012). Standar Kompetensi Dokter Indonesia. Perpustakaan Indonesia. Jakarta

11. Hilgren, A. A. (2008). Manager And The New Definition Of Quality. Journal of Healthcare Management, 53 (4): 221

12. Chang, C.-W., Tseng, T.-H. and Woodside, A.G. (2013), "Configural algorithms of patient satisfaction, participation in diagnostics, and treatment decisions'
126 Jurnal Manajemen dan Inovasi, Vol 8, No. 3, Oktober 2017 influences on hospital loyalty". Journal of Services Marketing, Vol. 27 No. 2, pp. 91-103

13. Anderson, Eugene W.; Fornell, Claes; Lehmann, Donald R. (2009). "Customer Satisfaction, Market Share and Profitability: Findings from Sweden". Journal of Marketing. Vol.58 (July 1994), pp.53-66.

14. Boquiren, Virginia M., Hack, T., Beaver, K., Williamson (2014) What do measures of patient satisfaction with doctor tell us. Behavioral Sciences \& Health Research Division, University Health Network PP 1-9.

15. Daft, R.L. (1998). Organization Theory and Design. Ohio: South-Western College Publishing.

16. Undang-undang Republik Indonesia Nomor 44 Tahun 2009 Tentang Rumah Sakit. Jakarta. Departemen Kesehatan RI.

17. East, Robert; Gendall, Philip; Hammond, Kathy ;Lomax,Wendy. (2005). Australasian Marketing Journal; 2005; 13, 2; pp. 10

18. Griffin, Jill. (2003) Customer Loyalty: Menumbuhkan dan Mempertahankan Kesetiaan Pelanggan. Jakarta: Penerbit Erlangga.

19. Dick, Alan S dan Basu, Kunal.1994. "Customer Loyalty: Toward an Integrated Conceptual Framework". Journal of the Academy of Marketing Science. Volume 22, No.2, pp.99-113. 